\title{
THE SERO-CONVERSION AND EVALUATION OF RENAL ALTERATIONS IN DOGS INFECTED BY Leishmania (Infantum) chagasi
}

Georgia Brenda Barros ALVES(1), Lucilene dos Santos SILVA(1), Joilson Ferreira BATISTA(2), Ângela Piauilino CAMPOS(1), Maria das Graças PRIANTI(1) \& Francisco Assis Lima COSTA(1)

\begin{abstract}
SUMMARY
This study investigated the sero-conversion period in which dogs from endemic areas test positive for visceral leishmaniasis (VL) as well as the early post-infection period in which renal alterations are observed. Dogs that were initially negative for Canine Visceral Leishmaniasis (CVL) were clinically evaluated every three months by serological, parasitological and biochemical tests until seroconversion was confirmed, and six months later a subsequent evaluation was performed. Samples of kidney tissues were processed and stained with Hematoxylin and Eosin (H\&E), Periodic Acid Schiff (PAS) and Masson's trichrome stain and lesions were classified based on the WHO criteria. Of the 40 dogs that initially tested negative for VL, 25 (62.5\%) exhibited positive serological tests during the study period. Of these $25 \mathrm{dogs}, 15$ (60\%) tested positive within three months, five (20\%) tested positive within six months and five (20\%) tested positive within nine months. The dogs exhibited antibody titers between 1:40 and 1:80 and $72 \%$ of the dogs exhibited clinical symptoms. The Leishmania antigen was present in the kidneys of recently infected dogs. We found higher levels of total protein and globulin as well as lower levels of albumin in the infected dogs when compared to the control dogs. Additionally, infected dogs presented levels of urea and creatinine that were higher than those of the uninfected dogs. Glomerulonephritis was detected in some of the dogs examined in this study. These data suggest that in Teresina, the sero-conversion for VL occurs quickly and showed that the infected dogs presented abnormal serum proteins, as well as structural and functional alterations in the kidneys during the early post-infection period.
\end{abstract}

KEYWORDS: Visceral Leishmaniasis; Seroconversion; Dogs; Kidney.

\section{INTRODUCTION}

Visceral Leishmaniasis (VL) is a form of zoonosis that is caused by protozoa of the genus Leishmania ${ }^{1,2}$. In Latin America, Leishmania (Infantum) chagasi is the predominant disease-causing species ${ }^{8,24,25,31,47,48}$. Infected dogs can exhibit a marked humoral immune response characterized by high levels of IgG anti-Leishmania antibodies, which, despite their upregulation, do not confer protection ${ }^{20}$. It is estimated that the time between infection and sero-conversion ranges from three months to seven years ${ }^{6}$.

Despite the wide range of tests already developed, the indirect fluorescent antibody test (IFAT) is the conventional method that is currently employed for epidemiological canine surveys. The euthanasia of dogs that test positive is a measure recommended by the Ministry of Health for the control of VL $\mathrm{VL}^{16,34,37,43}$. This measure was recommended as the result of canine populations constituting a major reservoir of the disease, representing the threat of canine-to-human disease transmission $^{3,35}$. The determination of the precise CVL sero-conversion period in endemic areas therefore represents an important factor in the control of VL.

By IFAT, dogs with high antibody titers are associated with active parasitism, the presence of clinical symptoms ${ }^{16}$ and an elevated probability of the presence of amastigotes as detected by parasitological examination ${ }^{17,40,42}$. It has therefore been suggested that the serological profile be used as an indicator for susceptibility or resistance to $\mathrm{CVL}^{5,16}$.

Dogs affected with VL generally present with renal changes ${ }^{11}$, manifested specifically by glomerulonephritis and interstitial nephritis ${ }^{14}$. Despite the high prevalence of renal pathologies, the development of renal failure is only evident when two thirds to three quarters of the renal tissue in both kidneys is compromised ${ }^{27}$.

Kidney disease in CVL can progress from mild proteinuria to nephrotic syndrome, developing progressively into renal failure, which is the leading cause of death among dogs ${ }^{11}$. The clinical evolution of CVL

(1) Departamento de Clínica e Cirurgia Veterinária, Setor de Patologia Animal, Centro de Ciências Agrárias, Teresina, PI, Brazil.

(2) Departamento de Clínica e Cirurgia Veterinária, Laboratório de Sanidade Animal, Centro de Ciências Agrárias, Universidade Federal do Piauí, Teresina, PI, Brazil.

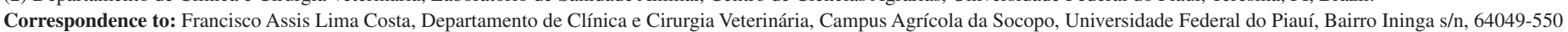
Teresina, Piauí, Brasil. E-mail: fassisle@gmail.com 


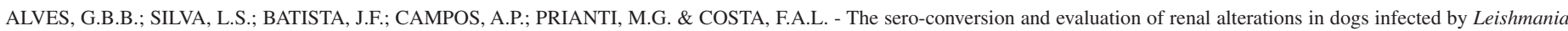
(Infantum) chagasi. Rev. Inst. Med. Trop. Sao Paulo, 55(2): 105-12, 2013.

therefore promotes serological, parasitological and biochemical changes which directly correlate with the clinical status of the affected dog.

This study aims to define the time period in which dogs seroconvert during VL infection in the endemic area of Teresina in the state of Piauí, and to evaluate the functional and structural impairment of the kidneys during the early post-infection period.

\section{MATERIALS AND METHODS}

From a population of $88 \mathrm{dogs}$ from the University Veterinary Hospital, $40(70.1 \%)$ dogs which tested negative for VL were monitored in their homes every three months for one year. The dogs examined in this study ranged from eight months to 12.2 years of age and both males and females of undefined races were included. The animals were evaluated clinically for the diagnosis of CVL and were subjected to blood collection, bone marrow aspiration and popliteal lymph node biopsy under sedation and local anesthesia.

The detection of Leishmania using anti-Leishmania antibodies was performed by IFAT (lote 08ULC0127/Biomanguinhos/FIOCRUZ, Rio de Janeiro, RJ, Brazil) in sera diluted at 1:40, 1:80, 1:160 and 1:320. Parasitological examinations were performed on smears of popliteal lymph node aspirates and bone marrow samples. The uninfected dogs were monitored by clinical and parasitological examination and IFAT at the homes of their owners every three months for a maximal period of one year until the time of sero-conversion, whereupon the dogs were separated into the following three groups: 11 dogs with anti-Leishmania antibodies and more than three clinical symptoms for VL (seropositive), seven dogs with anti-leishmania antibodies and up to three clinical symptoms for VL (seropositive) and seven dogs exhibiting positive serology (seropositive) and no clinical symptoms for $\mathrm{VL}^{41}$. The control group was comprised of 11 uninfected dogs without clinical symptoms for VL. For clinical evaluation, we considered the following manifestations: skin lesions, lymphadenopathy, onychogryphosis, weight loss, alopecia, conjunctivitis, pale mucous membranes, muzzle keratinization, depigmentation of the muzzle, edema and apathy.

The characterization of Leishmania species was performed using PCR on kidney samples from dogs exhibiting positive serological profiles for VL, using sequences from the ITS (internal transcribed spacer) of the ribosomal RNA (rRNA) gene.

The experimental protocols used in this study were approved by the Ethics Committees on Animal Experimentation of the Federal University of Piauí under No. 015/2010.

After an interval of five months of sero-conversion, blood samples were further collected from nine dogs exhibiting positive serology to monitor renal function.

Serum samples were used to assess the levels of urea (Labtest No. 104-4), creatinine (kit Labtest No. 35), total protein (Labtest No. 99) and albumin (Labtest No. 19) using the semi-automated SB 190 method. The results were analyzed based on normal values for the species ${ }^{22}$.

We evaluated 40 dogs which tested negative for CVL and were distributed among various neighborhoods of the city of Teresina in the state of Piauí, including the districts of moderate transmission (Santo Antonio, Angelim and Satélite ${ }^{18}$. The twenty-seven total neighborhoods in the city of Teresina visited to collect materials were distributed among five urban areas: Central, North, East, South and Southeast ${ }^{45}$.

The six dogs that were determined to be positive for VL by serological or parasitological examination and that presented more than three clinical symptoms for VL (seropositive) were enrolled for study with the permission of the owners, who signed a consent form. The dogs were transported to the sector of Animal Pathology of UFPI, where they were anesthetized with sodium thiopental $25 \mathrm{mg} / \mathrm{kg}$ intravenously ${ }^{15,32}$, euthanized and necropsied to collect kidney samples. The tissue samples were formalin-fixed, paraffin-embedded and then processed and stained with H\&E, PAS and Masson's trichrome stains ${ }^{27}$. Other renal tissue samples were prepared and subjected to immunohistochemical analysis using a mouse polyclonal, anti-Leishmania amazonensis antibody at a dilution of 1:400 and the EnVision + peroxidase system for the amplification reaction (Dako Corporation Carpinteria, CA, USA, catalog number K4002). The signal development was performed using $0.3 \mathrm{mg} / \mathrm{mL}$ 3,3'-diaminobenzidine in PBS containing $0.06 \%$ hydrogen peroxide and counterstained with Harry's hematoxylin stain.

The renal abnormalities were classified according to the criteria of the World Health Organization to define the morphological patterns of glomerulonephritis ${ }^{9,51}$. The data were tabulated, graphed and analyzed using Sigma Stat statistical software (Bioestat, 5.0) for non-parametric tests (Mann-Whitney U test). $p$-values $<0.05$ were considered statistically significant.

\section{RESULTS}

From a population of $88 \mathrm{dogs}$ from the University Veterinary Hospital, $57(64.7 \%)$ dogs that initially tested negative for CVL comprised the sero-conversion study group in our investigation. Of this group, $40 \mathrm{dogs}$ $(70.1 \%)$ were monitored in their homes every three months for one year.

Of the 40 dogs that initially tested negative for VL, $25(62.5 \%)$ exhibited positive serologic tests during the study period. Of these dogs, $15(60 \%)$ tested positive within three months ( $2^{\text {nd }}$ serum collection), five (20\%) tested positive within six months ( $3^{\text {rd }}$ serum collection) and five (20\%) tested positive within nine months ( $4^{\text {th }}$ serum collection).

The PCR performed on samples of renal tissue from three dogs confirmed that the infection was caused by Leishmania (infantum) chagasi.

At the 12-month follow-up of the VL-positive dogs, 11 (44\%) developed more than three clinical symptoms, seven (28\%) presented up to three clinical symptoms and seven (28\%) did not develop clinical symptoms. The percentage of dogs that tested positive for VL without manifesting clinical symptoms was therefore less (28\%) than that of animals that presented clinical symptoms (72\%). Clinical symptoms, such as lymphadenopathy and skin lesions, were the most frequent manifestations observed (Fig. 1).

Of the 18 dogs presenting clinical manifestations of VL (11 with more than three clinical symptoms and seven with up to three symptoms), 10 tested positive within an interval of three months (seven with more than three clinical symptoms and three with up to three clinical symptoms) 

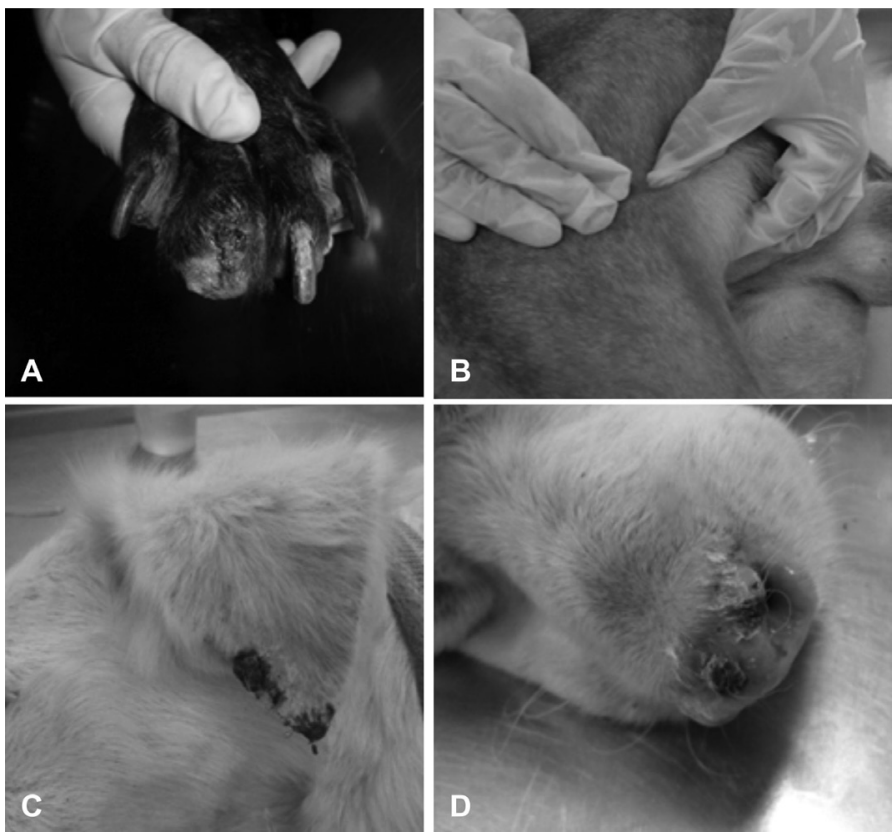

Fig. 1 - Clinical manifestations observed in dogs naturally infected with L (Infantum) chagasi in the early post-infection period. (A) Onychogryphosis and skin lesions (ungueal region). (B) Enlarged popliteal lymph node. (C) Skin lesions (ear). (D) Skin lesions (muzzle).

and in the group of dogs without clinical symptoms, five also tested positive within an interval of three months. The largest number of dogs that tested positive for VL during the study period were those located within the urban neighborhoods of the North (24\%) and South (24\%), followed by the urban neighborhoods of the Central (20\%), East (16\%) and Southeast $(16 \%)$ regions.

To evaluate the main indices of the health status of these animals that might contribute to disease progression, we performed serological and biochemical tests to evaluate renal function, followed by histopathological examination of the kidney tissue samples.

The majority of the dogs presented serological titers of antiLeishmania antibodies between 1:40 and 1:80, regardless of their presentation of clinical symptoms. Although we found higher values of urea, creatinine and total protein in infected dogs than in uninfected dogs (Table 1), the differences that we observed were not significant. However, comparison of the data revealed that total protein (MannWhitney rank sum test, $p=0.0302$ ) and globulin (t-test, $p=0.0214$ ) values were significantly higher and that albumin values were (t-test, $p$ $=0.0386$ ) significantly lower in the infected dogs presenting with more than three clinical symptoms compared to the dogs in the control group (Fig. 2). The results of the biochemical measurements of the infected and uninfected dogs as well as the reference values are shown in Table 1.

Renal function tests revealed that among the 25 infected dogs, two $(8 \%)$ presented with urea (dogs No. 20 and 23) and creatinine (dogs No. 2 and 10) levels that were above the normal range (Table 1). In general however, infected dogs presented with elevated blood urea nitrogen (BUN) and creatinine levels that were higher than in uninfected dogs (Fig. 3), although the differences were not significant.

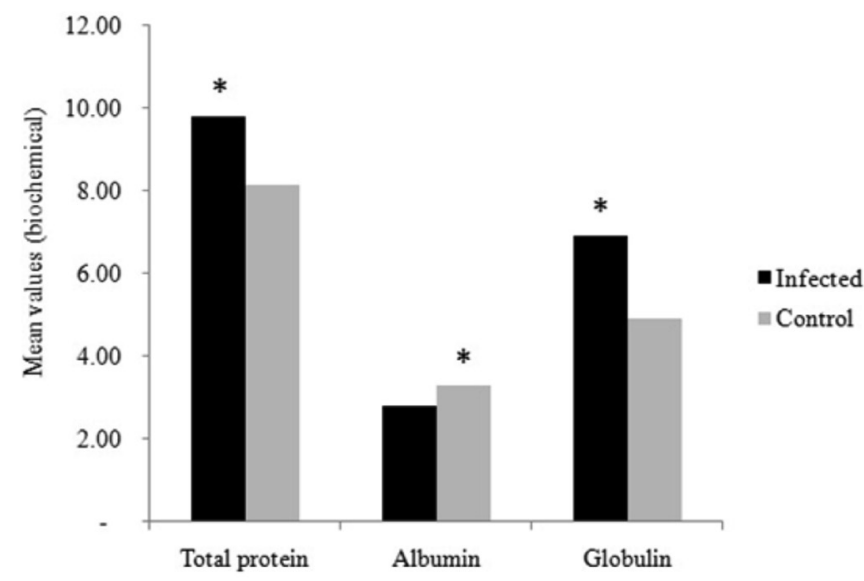

Fig. 2 - The mean values of total proteins, albumin and globulin in the serum samples of 11 control dogs and 11 naturally infected dogs by Leishmania (Infantum) chagasi presenting with more than three clinical symptoms, $* p<0.05$.

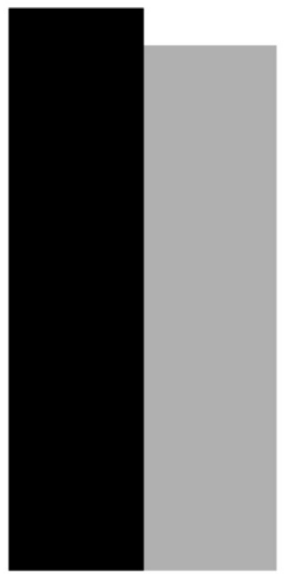

- INFECTED

CONTROL

Fig. 3 - The mean values of urea (U) and creatinine (C) in control dogs compared to dogs naturally infected by Leishmania (Infantum) chagasi in an early post-infection period.

Six newly infected dogs were euthanized for histological examination to evaluate the renal lesions. All of the dogs presented with two or more clinical symptoms of VL, such as weight loss, keratinization on the nose, conjunctivitis, skin lesions, seborrhea, enlarged lymph nodes, onychogryphosis and alopecia.

Microscopic examination revealed glomerulonephritis (GN) in five dogs, minimal change GN in two dogs (dogs Nos. 14 and 16), focal segmental glomerulosclerosis in one dog (dog No. 13) (Fig. 4A) and membranoproliferative GN (Fig. 4B) in two dogs (dog No. 4 and 8), according to previously described morphological characteristics ${ }^{12}$. The glomerular lesions were focal and of medium intensity. Perivascular mononuclear inflammatory infiltrates were observed in the corticomedullary and cortical regions that were proximal to blood vessels and tubules, ranging in intensity from minimal to average (Fig. 4C). Hyaline casts (Fig. 4D) were present in two dogs, one with minimal change GN and one with focal segmental glomerulosclerosis, which exhibited normal urea and creatinine levels. The PAS staining revealed the presence of medium intensity tubular atrophy with focal distribution 


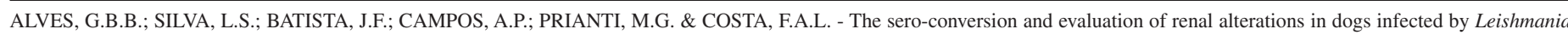
(Infantum) chagasi. Rev. Inst. Med. Trop. Sao Paulo, 55(2): 105-12, 2013.

Table 1

Results of biochemical tests of uninfected dogs and dogs that were naturally infected with Leishmania (Infantum) chagasi during a recent post-infection period. Teresina, Piauí, Brazil

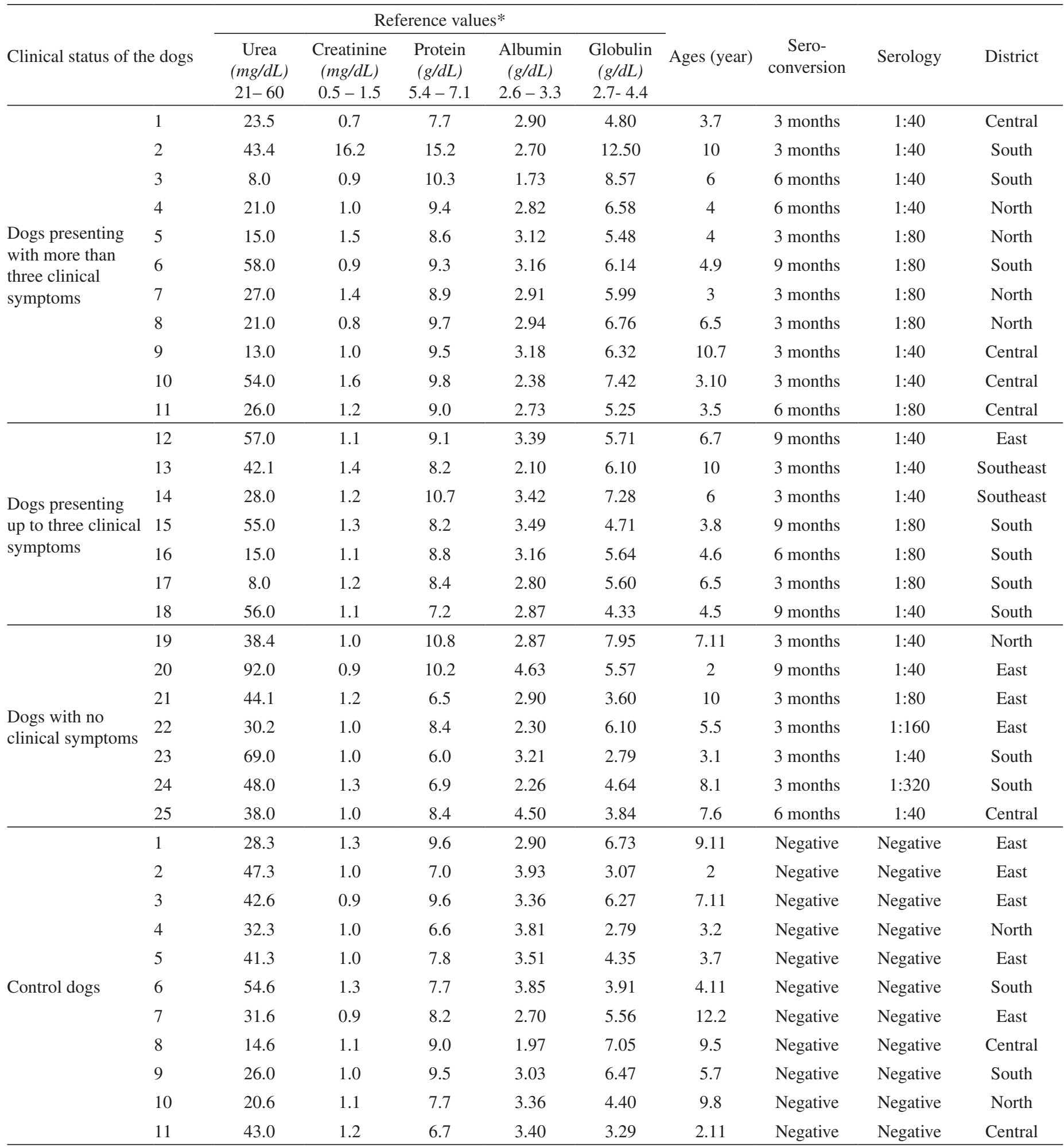

KANEKO et al., 2007. 


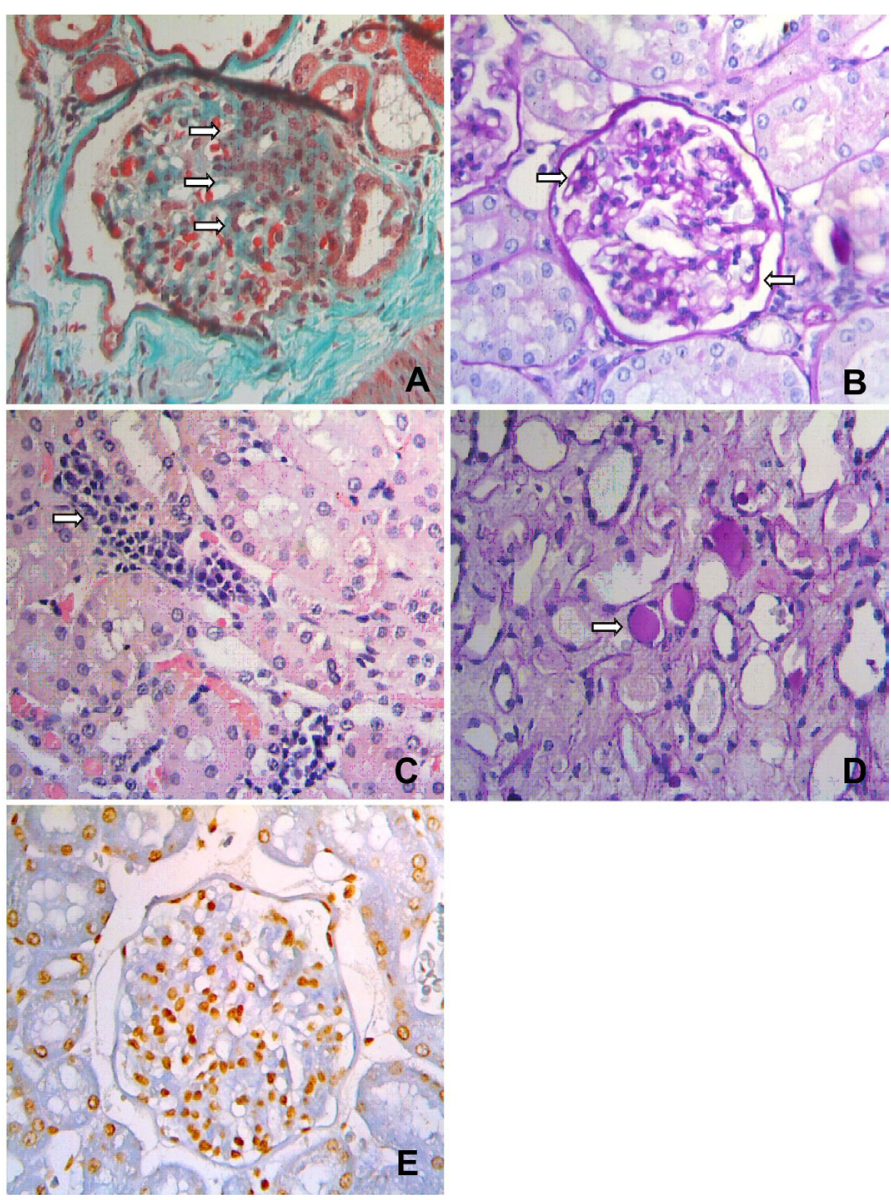

Fig. 4 - The kidney of a dog that was naturally infected by Leishmania (Infantum) chagasi (A) Focal segmental glomerulosclerosis (arrows) (dog No. 13). Trichrome Masson staining. Magnification: 40x. (B) Thickening of the capillary basement membrane glomerular (arrows) in case of membranoproliferative glomerulonephritis (dog No. 8). PAS staining. Magnification: 40x. (C) Mononuclear inflammatory infiltrate (arrow) (dog No. 8). H-E staining. Magnification: 40x. (D) Hyaline casts (arrow) (dog No. 16). PAS staining. Magnification: 40x. (E) Leishmania antigen in glomerular and tubular epithelial cells. Immunoperoxidase staining. Magnification: 40x.

in one dog. Immunostaining of the Leishmania antigen was observed in glomerular cells, in tubular epithelial cells (Fig. 4E) and in inflammatory cells of all the recently infected dogs.

\section{DISCUSSION}

Of the 40 dogs that tested negative, it was possible to monitor the 25 dogs that subsequently tested positive for VL during the study period. The loss of follow-up of $15 \mathrm{dogs}$ was attributed to the death of some dogs, the owners' absence due to travel which precluded the collection of material, the change of owners from other cities and even the refusal of owners to continue their participation in our study. Although such obstacles have been previously described by other studies ${ }^{49}$, these difficulties hampered the monitoring and evaluation of all of the animals.

We observed that the dogs in the endemic areas of Teresina became infected within a short period of time, with $60 \%$ seroconverting after three months of follow-up. Increased periods of sero-conversion were observed in similar studies. In the endemic areas of Rio de Janeiro, 60 dogs were examined and $50 \%$ became seropositive over one year ${ }^{49}$. A study of 23 dogs in an endemic area of Italy revealed that 19 dogs tested PCR- or IFAT-positive at eight months and that four dogs tested positive after 12 months $^{39}$. The results of sero-conversion in this study represent a unique epidemiological parameter for the endemic areas of Teresina, contributing to the improved control of VL. This new information can serve as a guideline for the sampling frequency for analysis, for the faster identification of seropositive dogs and for the expedited removal of the animals from the areas' transmission. Because of the findings highlighted above, similar studies have been conducted in other regions $s^{1,7,30,36,37,38,49}$. However, the results were unique to each particular endemic area because each area has its own specific characteristics related to the canine population, socio-economic conditions of the human population, health conditions, sanitation and vector populations with different densities.

During the one-year follow-up, we found that most of the 25 seropositive dogs presented with more than three clinical symptoms. A study of 12 dogs experimentally infected with L. infantum followed over a period of six months showed that all dogs became positive within four months after infection. The dogs presented with clinical symptoms such as lymphadenopathy and lesions of $\operatorname{skin}^{29}$, which are similar to the results of this study in which dogs were naturally infected.

Our results therefore suggest that even with short infection times, the presence of clinical manifestations contributes to the transmission of $\mathrm{VL}$, as has been demonstrated in other studies ${ }^{33,44,50}$. The dogs in Teresina can contribute greatly to the intensification of the infectious cycle of the disease, which is demonstrated by the high incidence of CVL in this city.

According to our results, a larger number of infected dogs were domiciled in the North and South urban districts of Teresina city. Currently, more intense control measures (vector control by spraying with insecticides) have been used in six districts of the urban zone of Teresina, two of which are located in the North district (Santa Maria da Codipi, Pedra Mole), three of which are in the South district (Santo Antonio, Angelim, Esplanada) and one in the Southeast district (Satellite). These districts are reported to have an average of three to five cases/year of human visceral leishmaniasis ${ }^{18}$, confirming its high transmissibility. The factors related to the high incidence of disease in these urban areas ${ }^{46}$ were associated with poor sanitation systems. Of the 169,771 households in Teresina, only 22,108 (13.06\%) have a general network of sewers ${ }^{18}$. These areas are characterized by high levels of poverty, low-income families, households with poor living conditions, unpaved streets, close proximity to natural lakes surrounded by slums as observed in the Northern region and poor infrastructure, all of which contribute to the high transmission rates of $\mathrm{VL}^{18}$.

In general, the dogs that become seropositive for VL and that are more susceptible to the disease have high titers of anti-Leishmania antibodies ${ }^{20}$. In the present study, we found low titers of anti-Leishmania antibodies among the dogs examined. In this regard, there are two serological profiles for dogs with VL. The first is a profile in which the animals initially have low antibody titers which remain low, whereas in the other profile the dogs start with low antibody titers but they tend to increase over the period of infection ${ }^{49}$. Our study is consistent with these profiles because most of the dogs examined exhibited low antibody titers when they subsequently tested positive for VL, despite later developing 


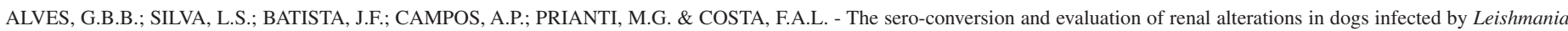
(Infantum) chagasi. Rev. Inst. Med. Trop. Sao Paulo, 55(2): 105-12, 2013.

clinical manifestations. The fact that most of the dogs in our study did not exhibit a positive parasitological examination can be explained by the low antibody titers observed, considering that a positive parasitological test is directly related to an increase in antibody titers ${ }^{28,40,42}$. This issue still requires further clarification because the dogs without clinical symptoms can exhibit high titers of antibodies without presenting parasitological positivity in the cultures of popliteal lymph node aspirate ${ }^{49}$.

Most of the dogs that seroconverted, especially the group presenting with more than three clinical symptoms, exhibited hyperproteinemia that was attributed to hyperglobulinemia and was significantly increased compared to the control dogs. These results revealed that even dogs that were recently infected exhibited changes in serum protein levels, indicating the importance of hyperproteinemia and particularly of hyperglobulinemia as potential diagnostic markers for CVL, consistent with previous studies ${ }^{14,19,43}$. In contrast, previous studies have also shown that dogs without clinical manifestations exhibited reduced antibody titers, lower levels of total protein and of globulin and increased albuminglobulin ratios ${ }^{4}$, which differs from our findings of hyperglobulinemia and hypoalbuminemia in infected dogs without clinical symptoms and is similar to dogs with clinical manifestations.

The increased levels of total protein, globulin, urea and creatinine and the lower levels of albumin observed in four infected dogs compared to control dogs indicate that dogs with VL tend to present with alterations in renal function at early stages of infection without the subsequent development of renal failure. Renal failure is a predominant cause of death in dogs with progressive VL ${ }^{11}$. Studies of chronically infected dogs of the endemic areas of São José de Ribamar in the state of Maranhão found high levels of urea, without changes in creatinine levels ${ }^{14}$. These higher levels of urea in a greater number of dogs might be attributed to pre-existing liver disease ${ }^{26}$, which is a possibility that we cannot exclude for the dogs examined in this study since VL can cause liver damage ${ }^{44}$. AMUSATEGUI et al. ${ }^{4}$ showed that at advanced stages of CVL, the mean values of urea and creatinine were high, whereas the dogs in the initial phase of infection exhibited lower levels of antibodies. Furthermore, the levels of urea and creatinine did not differ from those found in control dogs, which is consistent with our findings. We suggest that the biochemical assessment of serum from dogs with VL should be taken into account together with other biochemical analyses to aid in the diagnosis and assessment of the progression of infection, as has also been proposed in other studies ${ }^{14,23}$.

The six infected dogs were euthanized for the collection of kidney tissue samples and the subsequent analysis of renal lesions. These dogs presented with clinical symptoms and exhibited positive serological or parasitological tests. The limited number of animals euthanized has been justified by difficulties also observed by SILVA et al. ${ }^{49}$, who reported that the elimination of dogs without clinical symptoms of VL is difficult, as the owners do not easily relinquish their dogs for euthanasia. Furthermore, we observed that many owners of infected dogs preferred treatment over euthanasia.

Using immunohistochemistry, the Leishmania antigen was observed in glomerular cells, tubular epithelial cells and interstitial inflammatory cells, confirming the relationship between Leishmania and renal lesions, which is consistent with our previous studies ${ }^{11,12,13}$. Two dogs with normal levels of urea and creatinine exhibited hyaline casts (Dogs. No. 4 and 16) in renal tubules, demonstrating that proteinuria can occur even in the absence of severe structural changes of the kidneys, as observed by light microscopy in the cases of minimal change GN and of medium intensity membranoproliferative $\mathrm{GN}^{51,52}$ present in these dogs.

The description of the patterns of glomerular lesions diagnosed in this study was previously described by COSTA et al. ${ }^{11}$. The results revealed that the glomerular lesions are present in the early phase of natural infection by Leishmania (Infantum) chagasi, although we cannot completely exclude the possibility of other pre-existing infections, even when examining resident dogs. In general, the glomerular and tubular interstitial changes were of low intensity, with mild elevation of BUN and creatinine levels in infected dogs compared to uninfected dogs. However, these changes were insufficient to cause renal failure, which is consistent with the results from nephropathy studies, emphasizing that the functional alterations of the kidneys are observed only when $2 / 3$ or $3 / 4$ of tissue from both kidneys is impaired ${ }^{10,21,26}$.

The infected dogs monitored for one year that were not euthanized after six months were again subjected to biochemical blood analyses to assess renal function. Based on biochemical evidence, there was no worsening of renal function. The renal changes that occur during the course of CVL progression are therefore likely to evolve slowly, as these changes were not detected by any biochemical tests regardless of the post-infection time period, but rather were detected by histopathological examination in the recently infected dogs.

Based on the results of this study, we found that Teresina seroconversion to CVL occurs within a short time period (within three months of exposure) and that the infected dogs are therefore quickly included in the epidemiological pool of VL transmitters, contributing to the maintenance and spread of the disease. Most newly infected dogs presented with clinical symptoms of VL but did not exhibit high titers of anti-Leishmania antibodies. The infected dogs exhibited changes in serum proteins as well as high levels of urea and creatinine compared to uninfected dogs, which are likely to result from the renal lesions which must be taken into account for the early diagnosis of VL. Finally, we suggest that the sero-epidemiological surveys for CVL in Teresina must be performed within shorter time periods than it is performed currently (annually).

\section{FUNDING}

This work was supported by the FAPEPI (Foundation for Research of the State of Piauí), which provided a Masters program scholarship.

\section{RESUMO}

Soro-conversão e avaliação das alterações renais em cães infectados por Leishmania (Infantum) chagasi

Este estudo investigou o período em que o cão torna-se positivo para leishmaniose visceral (VL) em área endêmica e as alterações renais no período recente pós-infecção. Cães negativos para VL foram avaliados clinicamente a cada três meses por testes sorológicos, parasitológicos e bioquímicos até a soro-conversão e seis meses após. Foram colhidos tecido renal de seis cães, submetidos a processamento de rotina e corados com HE, PAS e Masson e as lesões foram classificadas com base nos critérios da OMS. Dos 40 cães nagativos para VL, $25(62,5 \%)$ apresentaram sorologia positiva durante o estudo. Desses, $15(60 \%)$ 
tornaram-se positiva nos primeiros três meses, cinco (20\%) tornaram-se positivas dentro de seis meses e cinco $(20 \%)$ tornaram-se positivas dentro de nove meses. Os cães apresentavam títulos de anticorpos entre 1:40 e 1:80, e $72 \%$ mostraram sinais clínicos. Antígeno de Leishmania estava presente no rim. Foram encontrados níveis mais elevados de proteína total e globulina, e menores níveis de albumina em cães infectados quando comparados aos controles. Além disso, os cães infectados apresentaram níveis de uréia e creatinina maior do que os cães controles. Glomerulonefrite foi observada em cinco cães. Os resultados sugerem que em Teresina a soro-conversão para VL ocorre rapidamente e os cães apresentam proteínas séricas anormais e alterações na estrutura e função dos rins em um período recente pós-infecção.

\section{REFERENCES}

1. Almeida ABPF, Faria RP, Pimentel MFA, Dahroug MAA, Turbino NCMR, Sousa VRF Inquérito soroepidemiológico de leishmaniose canina em áreas endêmicas de Cuiabá, Estado de Mato Grosso. Rev Soc Bras Med Trop. 2009;42:156-9.

2. Alvar J, Yactayo S, Bern C. Leishmaniasis and poverty. Trends Parasitol. 2006;22:552-7.

3. Alves WA, Bevilaqua PD. Reflexões sobre a qualidade do diagnóstico da leishmaniose visceral canina em inquéritos epidemiológicos: o caso da epidemiologia de Belo Horizonte, Minas Gerais, Brasil, 1993-1997. Cad Saude Publica. 2004;20:259-65.

4. Amusategui I, Sainz A, Rodriguez F, Tesouro MA. Distribution and relationships between clinical and biopathological parameters in canine leishmaniasis. Eur J Epidemiol. 2003; 18:147-56

5. Ashford DA, Bozza M, Freire M, Miranda JC, Sherlock I, Eulalio C, et al. Comparison of the polymerase chain reaction and serology for the detection of canine visceral leishmaniasis. Am J Trop Med Hyg. 1995;53:251-5.

6. Baneth G. Leishmaniasis. In: Greene CE, editor. Infectious diseases of the dog and cat. III. London: Saunders-Elsevier; 2006. p. 685-98.

7. Barboza DCPM, Gomes Neto CMB, Lea DC, Bittencourt DVV, Carneiro AJB, Souza BMPS, et al. Estudo de coorte em áreas de risco para leishmaniose visceral canina, em municípios da região metropolitana de Salvador, Bahia, Brasil. Rev Bras Saúde Prod An. 2006; 7:152-63.

8. Berman JD. Human leishmaniasis: clinical, diagnostic and chemotherapeutic developments in the last 10 years. Clin Infect Dis. 1997;24:684-703.

9. Churg J, Bernstein J, Glassock RJ. Renal disease: classification and atlas of glomerular diseases. New York: Igaku-Shoin; 1985.

10. Cook AK, Cowgill LD. Clinical and pathological features of protein-losing glomerular disease in the dog: a review of 137 cases (1985-1992). J Am Anim Hosp Assoc. 1996;32:313-22.

11. Costa FAL, Goto H, Saldanha LCB, Silva SMMS, Sinhorini IL, Silva TC, et al. Histopathologic patterns of nephropathy in naturally acquired canine visceral leishmaniasis. Vet Pathol. 2003;40:677-84.

12. Costa FAL, Guerra JL, Silva SM, Klein RP, Mendonça IL, Goto H. CD4+ T cells participate in the nephropathy of canine visceral leishmaniasis. Braz J Med Biol Res. 2000;33:1455-8

13. Costa FAL, Prianti MG, Silva TC, Silva SMMS, Guerra JL, Goto H. T cells, adhesion molecules and modulation of apoptosis in visceral leishmaniasis glomerulonephritis. BMC Infect Dis. 2010:10:112.

14. Dias EL, Batista ZS, Guerra RMSNC, Calabrese KS, Lima TB, Abreu-Silva AL. Canine visceral leishmaniasis (CLV): seroprevalence, clinical, hematological and biochemical findings of dogs naturally infected in an endemic area of São José de Ribamar municipality, Maranhão State, Brazil. Ci Anim Bras. 2008;9:740-5.
15. Dias MIR. Anestesia com indução pelo tiopental de sódio e manutenção pelo halotano no cão. Rev Port Ci Vet. 2000;95:71-80.

16. Dos-Santos WLC, Jesus EE, Paranhos-Silva M, Pereira AM, Santos JC, Baleeiro CO, et al. Associations among immunological, parasitological and clinical parameters in canine visceral leishmaniasis: emaciation, spleen parasitism, specific antibodies and leishmanin skin test reaction. Vet Immunol Immunopathol. 2008;123:251-9.

17. Dye C, Vidor E, Dereure J. Serological diagnosis of leishmaniasis: on detecting infection as well as disease. Epidemiol Infect. 1993;110:647-56.

18. Gezoon. Gerência de Zoonozes de Teresina, Piauí. Teresina; 2010.

19. Giunchetti RC, Mayrink W, Carneiro CM, Corrêa-Oliveira R, Martins-Filho OA, Marques MJ, et al. Histopathological and immunohistochemical investigations of the hepatic compartment associated with parasitism and serum biochemical changes in canine visceral leishmaniasis. Res Vet Sci. 2008;84:269-77.

20. Gradoni L. The diagnosis of canine leishmaniasis. In: Canine leishmaniasis: moving towards a solution, 2002, Sevilla. Proceedings of the Second International Canine Leishmaniasis Forum. Sevilla; 2002. p. 7-15.

21. Grauer GF. Glomerulonephritis. Semin Vet Med Surg (Small Anim.). 1992;7:187-97.

22. Kaneko JJ, Harvey DW, Bruss WL. Clinical biochemistry of domestic animals V. San Diego: Academic Press; 1997.

23. Koutinas AF, Polizopoulou ZS, Saridomichelakis MN, Argyriadis D, Fytianou A, Plevraki KG. Clinical considerations on canine visceral leishmaniasis in Greece: a retrospective study of 158 cases (1989-1996). J Am Anim Hosp Assoc. 1999;35:376-83.

24. Lainson R, Shaw JJ. A brief history of the genus Leishmania (Protozoa: Kinetoplastida) in the Americas with particular reference to Amazonian Brazil. Ci Cult. 1992;4:94106.

25. Lainson R, Shaw JJ. Evolution, classification and geographical distribution. In: Peters W, Lillick-Kendrick R. The leishmaniasis in biology and medicine. London: Academic Press; 1987.

26. Lopes STA, Biondo AW, Santos AP. Manual de patologia clínica veterinária. Santa Maria: UFSM - Universidade Federal de Santa Maria; 2007.

27. Luna GL. Manual of histologic staining methods of the Armed Forces Institute of Pathology. $3^{\text {rd }}$ ed. New York: McGraw Hill; 1968.

28. Madeira MF, Figueiredo FB, Pinto AG, Nascimento LD, Furtado M, Mouta-Confort E, et al. Parasitological diagnosis of canine visceral leishmaniasis: is intact skin a good target? Res Vet Sci. 2009;87:260-2.

29. Maia C, Nunes M, Cristóvão J, Campino L. Experimental canine leishmaniasis: clinical, parasitological and serological follow-up. Acta Trop. 2010;116:193-9.

30. Matos MM, Filgueira KD, Amora SSA, Suassuna ACD, Ahid SMM, Alves ND. Ocorrência da leishmaniose visceral em cães em Mossoró, Rio Grande do Norte. Ci Anim. 2006; $16: 51-4$

31. Maurício IL, Stothard JR, Miles MA. The strange case of Leishmania chagasi. Parasitol Today. 2000;16:188-9.

32. Melby Jr EC, Altman NH. Handbook of laboratory animal science III. Miami: CRC Press; 1976.

33. Michalsky EM, Rocha MF, Lima ACR, França-Silva JC, Pires MQ, Oliveira FS, et al. Infectivity of seropositive dogs, showing different clinical forms of leishmaniasis, to Lutzomyia longipalpis phlebotomine sand flies. Vet Parasitol. 2007;147:67-76.

34. Ministério da Saúde. Brasil. Manual de vigilância e controle da leishmaniose visceral. Brasília; 2006. 
ALVES, G.B.B.; SILVA, L.S.; BATISTA, J.F.; CAMPOS, A.P.; PRIANTI, M.G. \& COSTA, F.A.L. - The sero-conversion and evaluation of renal alterations in dogs infected by Leishmania (Infantum) chagasi. Rev. Inst. Med. Trop. Sao Paulo, 55(2): 105-12, 2013.

35. Molina R, Amela C, Nieto J, San-Andrés M, González F, Castillo JA, et al. Infectivity of dogs naturally infected with Leishmania infantum to colonized Phlebotomus perniciosus. Trans R Soc Trop Med Hyg. 1994;88:491-3.

36. Moshfea A, Mohebalia M, Edrissiana G, Zarei Z; Akhoundia B, Kazemid B, et al. Canine visceral leishmaniasis: asymptomatic infected dogs as a source of $L$. infantum infection. Acta Trop. 2009;112:101-5.

37. Oliveira LCP, Araújo RR, Alves, CR, Mouta-Confort E, López JA, Mendonça-Lima FW. Seroprevalence and risk factors for canine visceral leishmaniasis in the endemic area of Dias D’Ávila, State of Bahia, Brazil. Rev Soc Bras Med Trop. 2010;43:400-4.

38. Otranto D, Paradies P, De Caprariis D, Stanneck D, Testini G, Grimm F, et al. Toward diagnosing Leishmania infantum infection in asymptomatic dogs in an area where leishmaniasis is endemic. Clin Vaccine Immunol. 2009;16:337-43.

39. Paradies P, Sasanelli M, De Caprariis D, Testini G, Traversa D, Lia RP, et al. Clinical and laboratory monitoring of dogs naturally infected by Leishmania infantum. Vet J. 2010;186:370-3.

40. Pinelli E, Killick-Kendrick R, Wagenaar J, Bernardina W, Del Real G, Ruitenberg J. Cellular and humoral responses in dogs experimentally and naturally infected with Leishmania infantum. Infect Immun. 1994;62:229-35.

41. Pozio E, Grandoni L, Bettini S, Gramiccia M. Leishmaniasis in Tuscany (Italy). VI. Canine leishmaniasis in the focus of Monte Argentario (Grosseto). Acta Trop. 1981;38:38393.

42. Quinnell RJ, Courtenay O, Garcez LM, Kaye PM, Shaw MA, Dye C, et al. IgG subclass responses in a longitudinal study of canine visceral leishmaniasis. Vet Immunol Immunopathol. 2003;91:161-8.

43. Reis AB, Martins-Filho OA, Teixeira-Carvalho A, Carvalho MG, Mayrink W, FrançaSilva JC, et al. Parasite density and impaired biochemical/hematological status are associated with severe clinical aspects of canine visceral leishmaniasis. Res Vet Sci. 2006;81:68-75
44. Reis AB, Martins-Filho OA, Teixeira-Carvalho A, Giunchetti RC, Carneiro CM, Mayrink $\mathrm{W}$, et al. Systemic and compartmentalized immune response in canine visceral leishmaniasis. Vet Immunol Immunopathol. 2009;128:87-95.

45. Secretaria do Planejamento do Piauí. Bairros. Teresina, PI, 2010. [Cited: 2010 Dec 20] Available from: <http://www.teresina.pi.gov.br:8080/semplan/thebairros.asp>

46. Secretaria Estadual da Saúde do Piauí. Coordenação de Vigilância em Saúde Ambiental. Programa de Controle das Leishmanioses. Série histórica de 1998 a 2008. Teresina; 2009.

47. Shaw JJ. Further thoughts on the use of the name Leishmania (Leishmania) infantum chagasi for the aetiological agent of American visceral leishmaniasis. Mem Inst Oswaldo Cruz. 2006;101:577-9.

48. Shaw JJ. New World leishmaniasis: the ecology of leishmaniasis and the diversity of leishmanial species in Central and South America. In: Farrell J. World Class Parasites: Leishmania. Boston: Kluwer Academic Publishers; 2002. p.11-31.

49. Silva AV, Paula AA, Pereira DP, Brazil RP, Carreira JCA. Canine leishmaniasis in Brazil: serological follow-up of a dog population in an endemic area of American visceral leishmaniasis. J Parasitol Res. 2009;2009:680790.

50. Soares MRA, Mendonça IL, Bonfim JM, Rodrigues JA, Werneck GL, Costa CHN. Canine visceral leishmaniasis in Teresina, Brazil: relationship between clinical features and infectivity for sand flies. Acta Trop. 2011;117:6-9.

51. Tisher CC, Brenner BM. Renal pathology: with clinical and functional correlations. 2. ed. Philadelphia: J. B. Lippincott; 1994.

52. Zatelli A, Borgarelli M, Santilli R, Bonfanti U, Nigrisoli E, Zanatta R, et al. Glomerular lesions in dogs infected with Leishmania organisms. Am J Vet Res. 2003;64:558-61.

Received: 17 May 2012

Accepted: 21 August 2012 